\title{
Accumulation dynamics and physicochemical variability of starch in cultivars of Canna edulis $\mathrm{Ker}^{1}$
}

\author{
Freddy Forero Longas ${ }^{2}$, Adriana Pulido Diaz ${ }^{3}$
}

\section{ABSTRACT}

Canna edulis, also known as achira or sagu, is widely grown in South America because its rhizomes are a major source of starch for food and agroindustry. This study aimed to assess the accumulation rate and physicochemical changes of starch from four canna cultivars (Verde, Nativa, Maituna and Morada), grown under a traditional system, in the southwest region of Colombia. The rhizomes were harvested after planting (between five and nine months) to extract and characterize the starch. It was found that the starch yield $(\% \mathrm{wb})$ was related to the plant development age, reaching a maximum at eight months for all cultivars $(12.78 \pm 0.19 \%$ - Verde; $12.46 \pm 0.18 \%$ Maituna; $12.17 \pm 0.19 \%$ - Nativa; $11.10 \pm 0.18 \%$ - Morada). The average chemical composition $(\% \mathrm{wb})$ of the native starch throughout the rhizome development, for all cultivars, was: $86.68 \%$ of starch, $1.12 \%$ of protein, $0.43 \%$ of dietary fiber, $0.14 \%$ of ash and $11.57 \%$ of moisture. At the optimum harvest age, the minimum and maximum amylose contents were $45.63 \%$ (Maituna) and $54.47 \%$ (Verde). The starch granule size among the cultivars showed a normal distribution, with a range of $40 \mu \mathrm{m}$ to $80 \mu \mathrm{m}$ and mean of $59.9 \mu \mathrm{m}$. The pasting curves per cultivar showed that the starch generated very high viscosity gels, unstable to the heating-cooling cycles, and high retrogradation.

KEYWORDS: Rhizome, agroindustry, flour.

\section{INTRODUCTION}

Throughout history, starch has been a fundamental food worldwide. It is found in all plant tissues, but it is most abundant in storage organelles called amyloplasts, which are present in seeds, tubers, roots and legumes (Šárka \& Dvořáček 2017). In corn and potato, each amyloplast contains a single starch granule called simple granule. When two or more granules occur in a single amyloplast, this is called

\section{RESUMO}

Dinâmica de acumulação e variabilidade físico-química do amido em cultivares de Canna edulis Ker

Canna edulis, também conhecido como achira ou sagu, é amplamente cultivado na América do Sul porque seus rizomas são boa fonte de amido para alimentos e agroindústria. Objetivou-se avaliar a taxa de acúmulo e as alterações físico-químicas do amido proveniente de quatro cultivares de canna (Verde, Nativa, Maituna e Morada), cultivadas sob sistema tradicional, na região sudoeste da Colômbia. Os rizomas foram colhidos após o plantio (entre cinco e nove meses) para extrair e caracterizar o amido. Verificouse que o rendimento de amido $(\% \mathrm{bu})$ estava relacionado à idade de desenvolvimento da planta, atingindo o máximo aos oito meses para todas as cultivares $(12,78 \pm 0,19 \%$ - Verde; $12,46 \pm 0,18 \%$ Maituna; $12,17 \pm 0,19 \%$ - Nativa; $11,10 \pm 0,18 \%$ - Morada). A composição química média ( $\%$ bu) do amido nativo, ao longo do desenvolvimento do rizoma, para todas as cultivares, foi: $86,68 \%$ de amido, $1,12 \%$ de proteína, $0,43 \%$ de fibra alimentar, $0,14 \%$ de cinza e $11,57 \%$ de umidade. Na idade ideal de colheita, os teores mínimo e máximo de amilose foram de 45,63\% (Maituna) e 54,47\% (Verde). O tamanho dos grânulos de amido entre as cultivares mostrou distribuição normal, com amplitude de $40 \mu \mathrm{m}$ a $80 \mu \mathrm{m}$ e média de $59,9 \mu \mathrm{m}$. As curvas de viscosidade por cultivar mostraram que o amido gerava géis de viscosidade muito alta, instáveis aos ciclos de aquecimento-resfriamento, e alta retrogradação.

PALAVRAS-CHAVE: Rizoma, agroindustria, farinha.

composite granule, as found in rice, oat, cassava root, sweet potato (Ipomoea batatas L.), sago (Metroxylon sp.) and dasheen (Colocasia esculenta) (Bemiller \& Whistler 2009).

Canna edulis Ker, also known as achira or sagu, is a perennial plant from the Cannaceae family, native to the South America Andean region, and cultivated mainly for its corms or rhizomes, which grow parallel to the soil surface. As a decoction, the rhizomes are used as a diuretic, the juice as an

1. Received: May 31, 2019. Accepted: Nov. 08, 2019. Published: Mar. 31, 2020. DOI: 10.1590/1983-40632020v5058827.

2. Universidad de Antioquia, Departamento de Alimentos, Medellin, Antioquia, Colombia.

E-mail/ORCID: freddy.forero@udea.edu.co/0000-0003-4189-4736.

3. Corporación Colombiana de Investigación Agropecuaria, C.I. La Selva, Rionegro, Antioquia, Colombia.

E-mail/ORCID: apulido@agrosavia.co/0000-0003-4654-1622. 
antiseptic, and the stems and leaves are used as fodder for livestock (Mishra et al. 2012). It is an important species for human consumption and agroindustry. The starch is easily digested and used to make bread, biscuits, cookies and tagliatelle (Huang et al. 2013a, Huang et al. 2013b). In the processing of protein-enriched $C$. edulis starch noodles, the native starch is pre-gelatinized by drum drying and, ultimately, noodles with the best cooking stability are obtained by mixing $12 \%$ of pre-gelatinized starch, $28 \%$ of native starch and $60 \%$ of water (Xie et al. 2019). This crop is currently harvested on a family and semi-commercial scale for starch production in small factories in Colombia, Brazil, China, Taiwan and Vietnam (Sjöö \& Nilsson 2018).

A study of the phenolic compounds and their antioxidant activity in C. edulis residue identified a new molecule [4-(3-(3,4-dihydroxyphenyl)acryloyl)-6hydroxy-1-methoxy-1,2,3,4-tetrahydronaphthalene2-carboxylic acid] in the water-soluble extract, with potential as a natural food additive (Zhang et al. 2011a). The C. edulis species is also a potential feedstock for ethanol production, because of its low nutrition requirements and the high starch content of its rhizomes. Reduction of the biomass viscosity by cell wall-degrading enzymes, including acid xylanase and $\beta$-glucanase, achieved $98.3 \%$ of mass fraction of the theoretical ethanol yield in a 5-L fermenter (Huang et al. 2013c).

The in vitro fermentabilities of raw and cooked canna starches and their derivatives showed that raw native canna starch generated butyric acid as a main short-chain fatty acid, while acetic acid was a major short-chain fatty acid derived from raw modified starches, highlighting this raw material as a potential source of these types of organic acid (Wandee et al. 2017). The processing of canna rhizomes to extract starch produces vast quantities of byproducts, composed mostly of cellulose and pectic substances. This soluble dietary fiber can be further used as a dietary supplement and additive in the food industry (Zhang \& Wang 2013).

Starch from Canna species presents opportunities to be used in food and pharmaceutical industries. Research that supports these applications recommends improving the production, extraction methods and starch quality (Andrade-Mahecha et al. 2015). It is important to remember that starches provide functional properties, both in manufacturing processes and final products. These properties are directly related to the chemical components and their physical structures, which depend mainly on their source of origin (Wandee et al. 2015).

This research aimed to identify the starch accumulation dynamics in rhizomes from four C. edulis cultivars produced in Huila (Colombia) and how the physicochemical properties change with the plant development, thereby contributing to improve the crop production system and to identify possible competitive advantages of this starch in the agroindustrial sector.

\section{MATERIAL AND METHODS}

Plants of C. edullis were cultivated at $1,700 \mathrm{~m}$ above the sea level in Palermo, Huila, Colombia, between January and September 2018, under an average temperature of $18^{\circ} \mathrm{C}$ and rainfall of $1,200 \mathrm{~mm}$.

Experimental sowing occurred in a randomized complete block design, with three blocks, each with four cultivars (Verde, Nativa, Maituna and Morada) and five replicates per cultivar. The plots consisted of five plants, for a total of 300 plants in the experiment. The land was leveled and weeded. Holes of $15 \mathrm{~cm} \times 15 \mathrm{~cm}$ and $30-\mathrm{cm}$ depth were opened at inter-hole distances of $1.0 \mathrm{~m} \times 1.0 \mathrm{~m}$, and filled with organic fertilizer $(500 \mathrm{~g})$. Weed control occurred manually every 15 days. According to technical recommendations, chemical fertilization and irrigation are unnecessary (Thitipraphunkul et al. 2003a).

The rhizomes were harvested every 30 days, from five to nine months. Harvesting involved manually tearing the plants with a shovel, shaking to loosen soil, cutting the stem base to separate rhizomes, and removing dry material, to finally pack and transport the plants to the processing site. Each sample (rhizomes of five plants per plot) was analyzed independently. Yield was evaluated based on the raw starch content. Laboratory-scale extraction was carried out based on a traditional procedure (Wandee et al. 2015).

Native starch from all cultivars was analyzed for moisture (AOAC 960.52), ash (AOAC 960.52), protein (AOAC 920.87 and using 6.25 as the crude protein factor) and dietary fiber, which was quantified by adopting a standard protocol (AOAC 985.29), using a TF-100 kit (Sigma-Aldrich). The starch content was estimated by the amylose/amyloglucosidase method, using an STA-20 kit (Sigma-Aldrich). The 
apparent amylose content was calculated based on the iodine-amylose complex formation (ISO 66471:2015), measured at $620 \mathrm{~nm}$ wavelength, using a spectrophotometer (Helios Zeta, Thermo Scientific), and quartz cuvette with $10 \mathrm{~mm}$ path length. The data were compared with an amylose/amylopectin standard curve ( $0 \%$ to $70 \%$ of amylose) that had a quadratic correlation coefficient $\left(r^{2}\right)$ of $99.3 \%$.

Granule size was measured using an optical microscope (Nikon Labophot-Pol) coupled with a 20-MP digital camera. Two starch suspensions per sample $(0.1 \% \mathrm{w} / \mathrm{v})$ were shaken for $5 \mathrm{~min}$, and then stained with an $\mathrm{I}_{2} / \mathrm{KI}$ solution $(0.2 \%)$. Before the observations at $\times 40$ magnification, a calibration was performed using a micrometric slide (Carl Zeiss) with $10-\mu \mathrm{m}$ divisions, determining that forty divisions of the eyepiece were equal to $204.88 \mu \mathrm{m}$. Then, the following equation was used to transform the observed starch granule diameter $(\mathrm{A}, \mu \mathrm{m})$ in respective size $(S, \mu \mathrm{m}): \mathrm{S}=(\mathrm{A} \times 204.88) / 40$.

In equiaxed granules, size was expressed as diameter, while, in non-equiaxed granules, size corresponded to the longest distance between granule edges. Measurements were made on a sample of 200 granules using the Image ${ }^{\circledR}$ software (NIH, USA), and size distributions were carried out using the Statgraphics Centurion $\mathrm{XV}^{\circledR}$ - PStatPoint Technologies (Perez 2002). In order to determine the pasting curves, starch suspensions were prepared at $10 \% \mathrm{w} / \mathrm{w}$ (10 g of starch in $100 \mathrm{~mL}$ of water). The mass of added water was corrected to a $12 \%$ moisture content basis. These solutions were transferred to a
Micro Visco-Amylo-Graph ${ }^{\circledR}$ (Brabender), where they were heated up to $95{ }^{\circ} \mathrm{C}$ at $6{ }^{\circ} \mathrm{C} \mathrm{min}-1$, held at $95^{\circ} \mathrm{C}$ for $3 \mathrm{~min}$ and then cooled to $50^{\circ} \mathrm{C}$ at the same rate, and held for $1 \mathrm{~min}$. The following variables were obtained from the generated curve: temperature at which the gel formation started $\left({ }^{\circ} \mathrm{C}\right)$, maximum temperature $\left({ }^{\circ} \mathrm{C}\right)$, maximum viscosity (Brabender units - BU), minimum viscosity (BU), final viscosity $(\mathrm{BU})$, breakdown (BU) and setback (BU).

The data were statistically adjusted by analysis of variance and means comparison (LSD) test (at $5 \%$ of significance) to verify if there were significant differences in the starch contents among the different growth stages for each cultivar. Correlation analyzes were also performed to identify the mathematical models that best described the change in physicochemical characteristics. Theses analyses were also performed using the Statgraphics software (Perez 2002).

\section{RESULTS AND DISCUSSION}

The starch accumulation dynamics in C. edulis rhizomes for each evaluated cultivar (Figure 1) revealed an increasing tendency of average starch yield $(\% \mathrm{wb})$ as the physiological age advanced, but only until eight months. At this point, the starch content decreased. Significant differences $(p<0.05)$ in the starch yields between cultivars were noted from the first sampling (five months). The average rate of starch accumulation between five and eight months was $1.55 \%$ to $2.11 \%$ (wb) by month, with

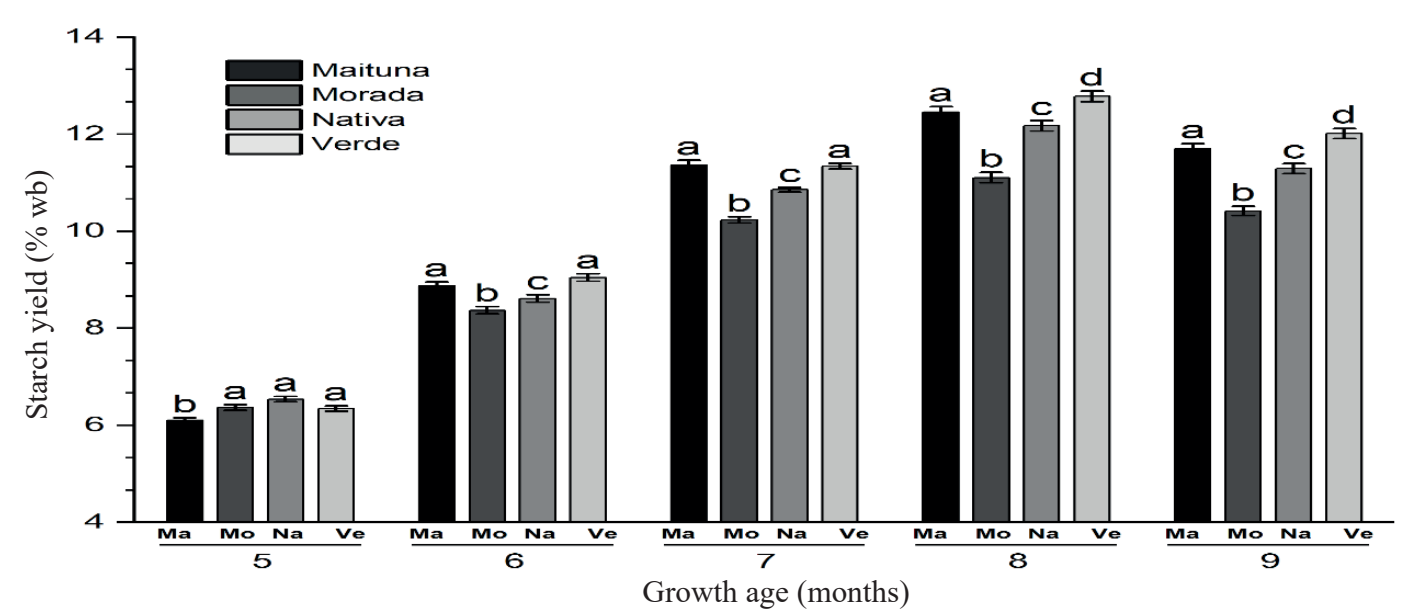

Figure 1. Starch yields variation in four Canna edulis cultivars at different vegetative growth ages (bars above each column represent standard errors of the means, which, if followed by the same letter for each month, do not differ in post hoc test at $5 \%$ of probability). 
the Morada and Verde cultivars representing the minimum and maximum, respectively.

To obtain the highest starch concentrations, the appropriate harvest time for all studied cultivars was eight months. With significant differences in the starch contents among cultivars, a multiple range analysis (LSD) was carried out obtaining three homogeneous groups ( $\%$ starch wb): Morada $11.10 \pm 0.18$ (group 1); Maituna $12.46 \pm 0.18$ and Nativa $12.17 \pm 0.19$ (group 2); Verde $12.78 \pm 0.19$ (group 3). This behavior may be affected by the climatic conditions in which the plant grows - total solar radiation, photoperiod and relative humidity (Fonseca-Florido et al. 2016).

The Verde cultivar stood out for its greater precocity and the largest number of rhizomes (between 45 and 60), which were ovoid and between $8 \mathrm{~cm}$ and $12 \mathrm{~cm}$ long, while Nativa presented a lower number of rhizomes, but with a larger size $(10-20 \mathrm{~cm})$. At the last sampling (nine months), an approximate $1 \%(\mathrm{wb})$ decrease in the starch yields was observed for all cultivars because, once the plant reaches its maximum leaf number, it starts consuming its reserves to sustain its aerial development (PagánJiménez et al. 2015).
From the proximal analysis data of all starch samples (Figure 2), the moisture content range was $10.55-13.49 \%$, which is adequate for this product. Under ambient temperature, commercial native starches contain around $12-17 \%$ of moisture, as a low water content favors their preservation and storage (Andrade-Mahecha et al. 2012). From the extracted raw starch, the net starch percentage increased slightly with the rhizome development, varying from $1.74 \%$ (Morada) to $3.64 \%$ (Nativa), with intermediate values of $2.13 \%$ (Verde) and $2.64 \%$ (Maituna). These data suggest that the net amount of starch does not change significantly after five months. This is consistent with the fact that the increase in rhizome size is the factor that most influences the raw starch yield.

The starch extracted from the cultivars at different physiological ages (months) had comparable protein amounts $(0.72-0.95 \% \mathrm{wb})$, which were higher than reported by Zhang \& Wang (2013) in C. edulis, but similar to potato starch (Klaochanpong et al. 2015). The low dietary fiber content, in comparison to other vegetable sources, is attributed to the protein contribution, decreasing the dietary fiber content by $0.20 \%$ (Verde), $0.22 \%$ (Nativa), $0.29 \%$ (Morada)
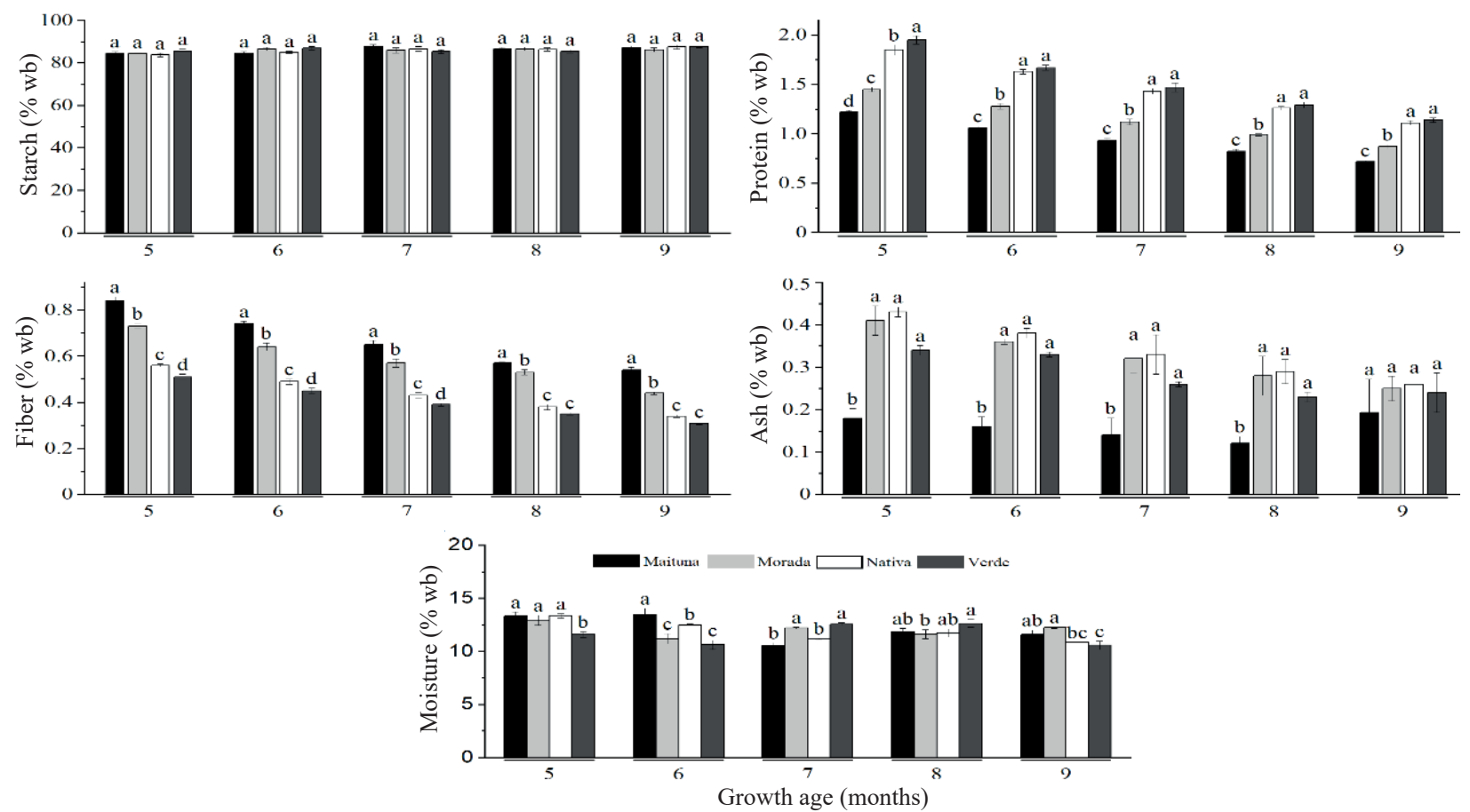

Figure 2. Native starch proximal composition (\% wb) in four Canna edulis cultivars at different vegetative growth ages (bars above each column represent standard errors of the means, which, if followed by the same letter for each month, do not differ in post hoc test at $5 \%$ of probability). 
and $0.50 \%$ (Maituna). The ash contents were within the range expected $(0.03-0.26 \%)$ from the literature data (0.18-0.33\%) (Puncha-Arnon et al. 2007).

In all cultivars, the starch exhibited a high amylose percentage, with averages of $43.09 \%$ as a minimum (five months) and $53.55 \%$ as a maximum (nine months). There was an increasing relationship between the amylose content and rhizome age (Figure 3), observed in all four cultivars. In contrast, amylopectin decreased progressively with the plant development, what corroborates another research (Lan et al. 2015). In other studies about canna starch structure (Thitipraphunkul et al. 2003b, Cisneros et al. 2009), amylose was categorized as medium-sized (1,500-1,600 degrees of polymerization, DPn), when compared with that in starch from other sources, such as potato $(4,370 \mathrm{DPn})$, sweet potato $(3,230 \mathrm{DPn})$, barley (1,580 DPn), wheat (1,220 DPn) and maize (1,030 DPn). Starch containing amylose with low polymerization degree produces unstable gels, but the high levels of such amylose present in C. edulis starch may be beneficial in improving film formation properties, as reported in the two referred studies.
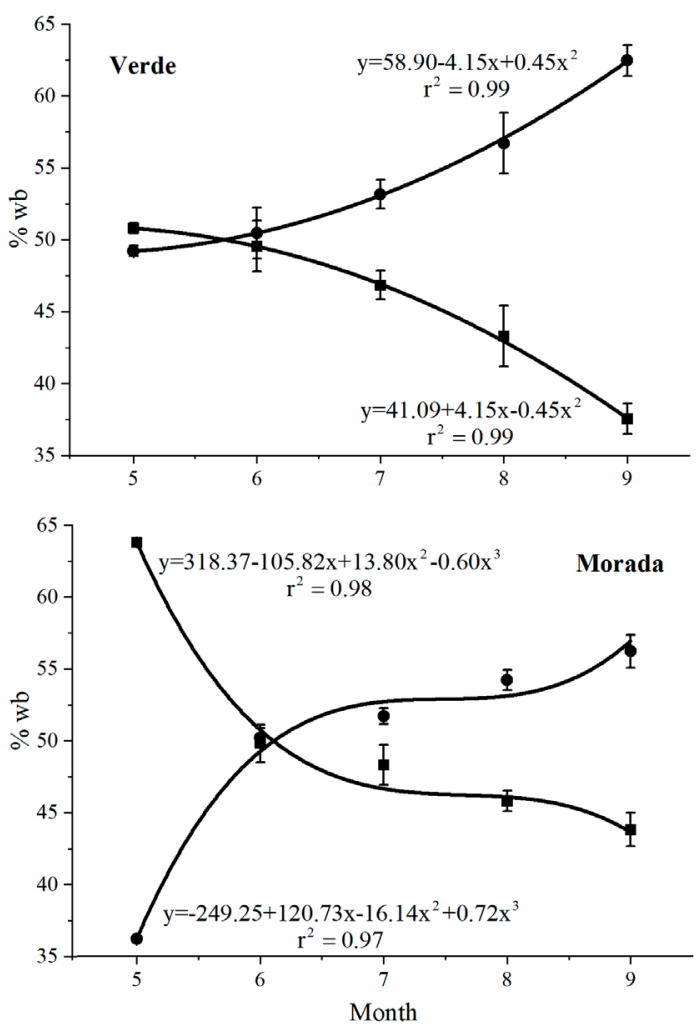

The Verde cultivar recorded the highest amylose contents throughout the analyzed period, while the Maituna ecotype always showed the lowest amylose values, with a maximum of $46.97 \%$ at nine months. The amylose-to-amylopectin ratio of starch greatly affects the starch functionality, including a gelatinization behavior and the final gel characteristics (Zhang \& Wang 2012).

There is often a positive correlation between amylose content and granule size, as found in the current analysis. However, this trend is not absolute, because many interacting factors influence the starch granule architecture and composition. It is expected that the gelatinization of starch with high amylose content, such as observed for C. edulis, will form a firm and cuttable gel. On the other hand, starch high in amylopectin will present a high viscosity peak, followed by a break during heating, without gel formation (Fonseca-Florido et al. 2018).

Besides the amylose and amylopectin contents, differences in the pasting properties may be attributed to the lipid content and the distribution of the amylopectin branches (in canna starch, it should be
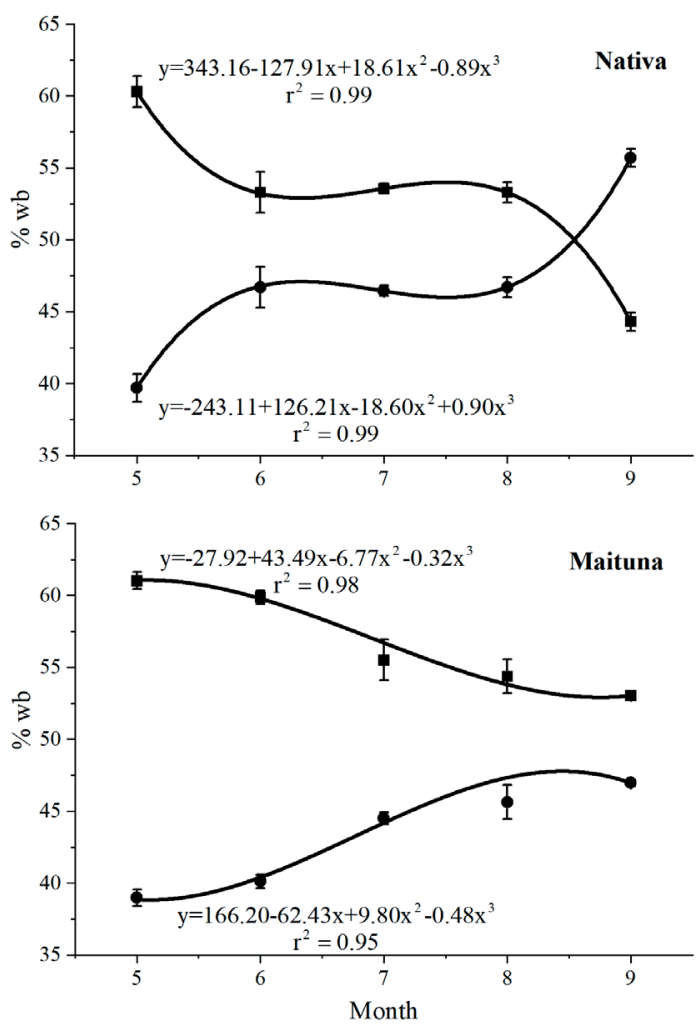

Figure 3. Contents $(\% \mathrm{wb})$ of amylose $(\bullet)$ and amylopectin $(\boldsymbol{\bullet})$ in the starch from four Canna edulis cultivars at different vegetative growth ages, in months (bars for each observed point represent the respective mean standard errors). 
remembered that amylopectin branches are longer than those present in cassava and bean starches), as long chains of amylopectin interact more easily with amylose, generating starch gels with more viscosity (Fuentes et al. 2019). In general, functional starch characteristics are determined not only by the whole granule properties, but also by its amylose and amylopectin components (Dhital et al. 2019).

Microscopic observations allow to identify differences in granule forms and appearances among starches. In the current study, the granules exhibited a smooth surface, oval and round shapes, with few broken granules, indicating low levels of starch damage during the extraction (Fonseca-Florido et al. 2017). All cultivars presented an average granule size between $38.14 \mu \mathrm{m}$ and $46.88 \mu \mathrm{m}$ for the first five to seven months of physiological age. The size distribution profiles for the optimum harvest time (eight months) are showed in Figures 4 and 5. It demonstrates a predominance of sizes between $40 \mu \mathrm{m}$ and $80 \mu \mathrm{m}$, with an average of $59.9 \mu \mathrm{m}$, which classifies it as a large-granule starch, in agreement with a previous study by Zhang et al. (2014).

These granule sizes in C. edulis suggest some possible applications. For example, granules smaller than $60 \mu \mathrm{m}$ are used in formulating cosmetic products because of their high-water absorption capacity, and as an encapsulating agent for flavors and dyes. The starch granule size is also an influential factor of starch digestibility and stability at high temperatures (Zhang et al. 2011b). The large size of the granules in canna starch confers it useful properties in the manufacture of traditional "Achiras" biscuits in the region of Huila (Colombia). Canna starch is used in the Asian cooking to make pasta, as well as a

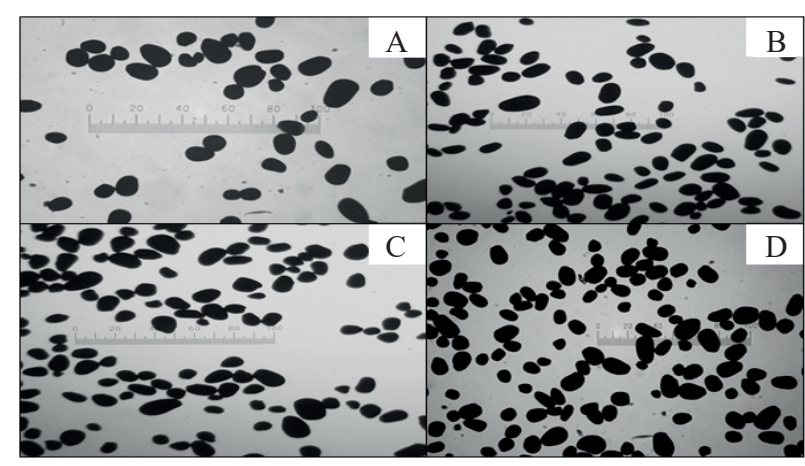

Figure 5. Starch granules micrographs (objective: $\times 40$ ) from four Canna edulis cultivars (A: Maituna; B: Morada; C: Nativa; D: Verde) for harvest at eight months.

thickener in soups and sauces, and, when modified, it has been used to encapsulate food ingredients, such as flavors (Andrade-Mahecha et al. 2012, GómezAldapa et al. 2019).

It was evidenced here that $C$. edulis starch granules are larger in relation to other sources, such as corn, cassava and potato, in which the average granule size is $12 \mu \mathrm{m}, 10 \mu \mathrm{m}$ and $48 \mu \mathrm{m}$, respectively (Puncha-Arnon et al. 2008). It has been proposed that larger granules gelatinize first and the smaller ones later, although this is not a universal standard, and smaller granules have a greater solubility, swelling power and water absorption capacity than larger granules (Zhang \& Wang 2012, Zhang \& Wang 2013).

The gelatinization process is defined as the collapse or disruption at the molecular level within the starch granule, manifesting irreversible changes in properties such as granule swelling, crystalline structure fusion, birefringence loss and solubilization
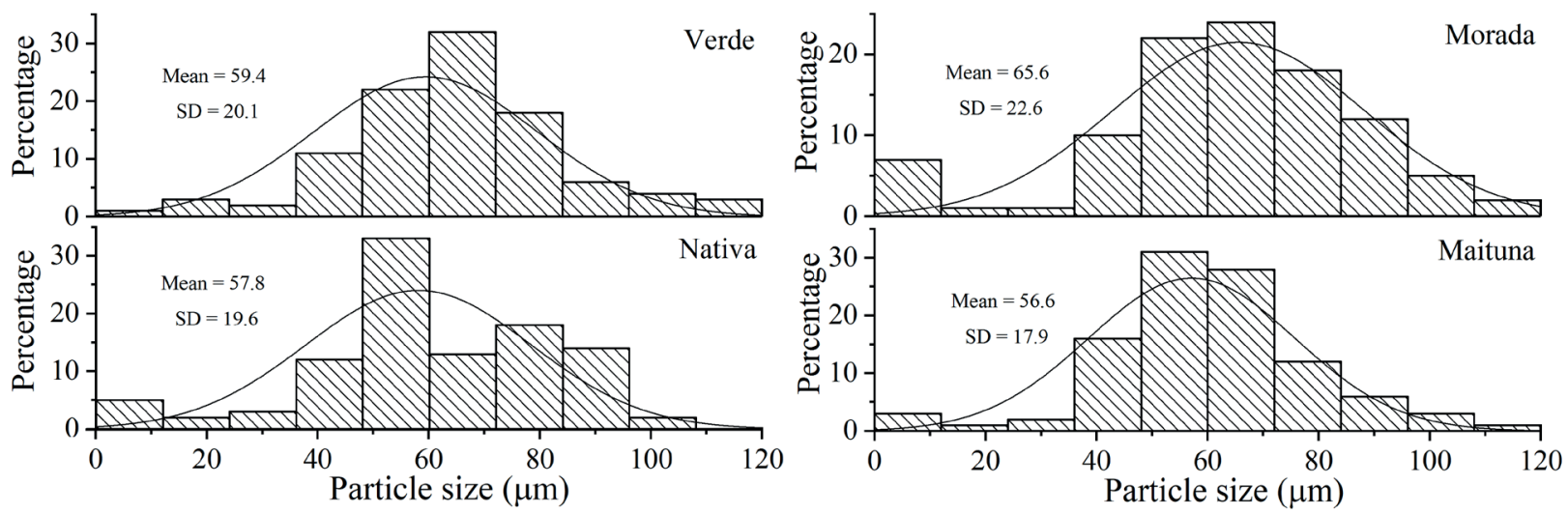

Figure 4. Size distribution of starch granules $(\mu \mathrm{m})$ in four Canna edulis cultivars for harvest at eight months. SD: standard deviation. 
(Pulido Díaz et al. 2017). The visco-amylo-graph profiles are shown in Figure 6. All samples presented approximately a similar behavior, including a high viscosity, instability throughout heating at $95^{\circ} \mathrm{C}$ and a moderate setback, although discrepancies were observed in the pasting variables. These differences in the gelatinization starting point and range over which it occurs might be a result of the starch concentration, observation method, granule type and granule population heterogeneity (Dewi 2009).

The starch gelatinization starting point was $63.6-66.6{ }^{\circ} \mathrm{C}$, and the highest gelatinization temperature was similar among all cultivars, with a difference of $1.8{ }^{\circ} \mathrm{C}$ between the maximum and minimum found. According to Grunina et al. (2015), this variation in the starch samples may be caused by differences in cropping practices, ecotypes or environmental conditions in which the plant grows.

Table 1 shows the changes in pasting parameters across the thermal process. The maximum viscosities were between $924 \mathrm{BU}$ and 1,210 BU, differences that may be attributed to the amylose and amylopectin chains distribution and amylose content (Huang et al. 2015). Starches of a relatively larger granule size (Verde and Morada cultivars) recorded the highest maximum viscosity. For all pastes, viscosity decreased considerably after heating at $95^{\circ} \mathrm{C}$, with Verde and Morada displaying the highest breakdown of $782 \mathrm{BU}$ and $735 \mathrm{BU}$, respectively, indicating a high instability. This starch behavior depends mainly on the amylose content and structural conformation. In processed foods, this phenomenon is considered very important, because of its association with properties such as stickiness, water absorption and digestibility (Jiranuntakul et al. 2011).

After cooling at $50{ }^{\circ} \mathrm{C}$, the final viscosity of all starches increased moderately, resulting in a minimum setback for Nativa (126 BU) and a maximum one for Morada (178 BU). After cooling the $C$. edulis starch, there is less available energy

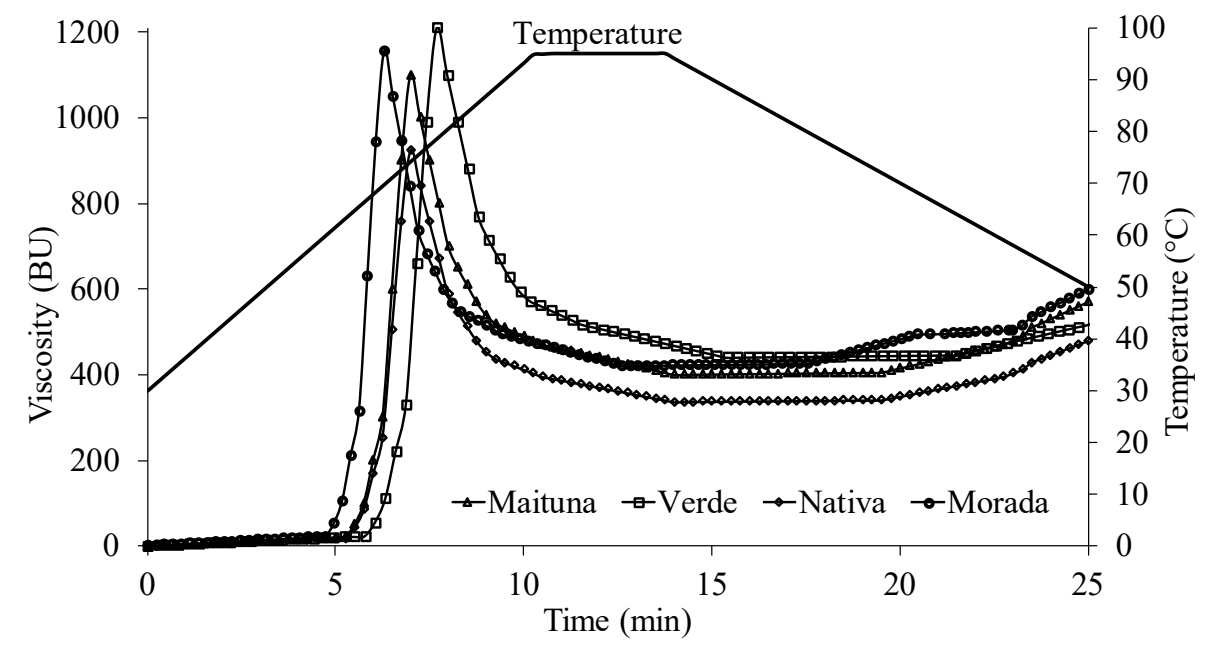

Figure 6. Starch visco-amylo-graphs from four Canna edulis cultivars, as a function of the temperature, for harvest at eight months. BU: Brabender units.

Table 1. Starch pasting properties (mean \pm standard error) from four Canna edulis cultivars, for harvest at eight months.

\begin{tabular}{lcccc}
\hline \multicolumn{1}{c}{ Properties } & \multicolumn{3}{c}{ Cultivars } \\
\cline { 2 - 5 } & Verde & Nativa & Maituna & Morada \\
\hline Gelatinization starting point $\left({ }^{\circ} \mathrm{C}\right)$ & $65.5 \pm 1.3$ & $66.6 \pm 0.7$ & $63.6 \pm 2.4$ & $66.5 \pm 1.8$ \\
Maximum temperature $\left({ }^{\circ} \mathrm{C}\right)$ & $71.2 \pm 1.2$ & $69.6 \pm 1.3$ & $69.4 \pm 1.2$ & $70.7 \pm 1.1$ \\
Maximum viscosity (BU) & $1,210 \pm 13.7$ & $924 \pm 10.8$ & $1,100 \pm 46.7$ & $1,155 \pm 13.7$ \\
Minimum viscosity (BU) & $440 \pm 14.4$ & $336 \pm 7.2$ & $400 \pm 7.6$ & $420 \pm 12.4$ \\
Final viscosity (BU) & $517 \pm 20.2$ & $462 \pm 18.6$ & $570 \pm 20.8$ & $598 \pm 15.5$ \\
Breakdown (BU) & $782 \pm 24.6$ & $558 \pm 0.8$ & $700 \pm 37.2$ & $735 \pm 18.4$ \\
Setback (BU) & $150 \pm 6.1$ & $126 \pm 6.5$ & $170 \pm 1.9$ & $178 \pm 2.7$ \\
\hline
\end{tabular}


to keep the solubilized starch molecules separated, because of the high amylose content, leading to crystalline aggregates and gel texture. Over time, this gel becomes gummy and tends to release water (syneresis), a phenomenon common in products such as sauces that have been formulated with amylose. The opposite trend is presented with starch of high amylopectin content, because it improves the texture and homogeneity of gelled starch, promoting starch gel stability when freezing and defrosting foods formulated with high-amylopectin starch (PunchaArnon et al. 2015). It must be remembered that Andean starches from rhizomes such as $C$. edulis exhibit higher viscosity values, when compared with corn (700 BU), wheat (250 BU) and rice (500 BU), but lower than for potato $(2,900 \mathrm{BU})$ and tapioca (1,200 BU) (Dhital et al. 2019).

\section{CONCLUSION}

The starch accumulation rate in Canna edulis rhizomes varied with the plant development, revealing that eight months is the optimum harvest point for the conditions and vegetal material studied. The Verde and Maituna cultivars registered the highest yields in raw starch. The physicochemical composition was similar among all the cultivars, highlighted by a high amylose content, and a high percentage of large starch granules was evident from the size distribution analysis. The pasting behavior showed a marked tendency to generate high viscosity gels, unstable to the heating-cooling process, high retrogradation, and a moderate recovery of the final viscosity.

\section{REFERENCES}

ANDRADE-MAHECHA, M. M.; PELISSARI, F. M.; TAPIA-BLÁCIDO, D. R.; MENEGALLI, F. C. Achira as a source of biodegradable materials: isolation and characterization of nanofibers. Carbohydrate Polymers, v. 123, n. 1, p. 406-415, 2015.

ANDRADE-MAHECHA, M. M.; TAPIA-BLÁCIDO, D. R.; MENEGALLI, F. C. Development and optimization of biodegradable films based on achira flour. Carbohydrate Polymers, v. 88, n. 2, p. 449-458, 2012.

BEMILLER, J.; WHISTLER, R. Starch. 3. ed. San Diego: Academic Press, 2009.

CISNEROS, F. H.; ZEVILLANOS, R.; CISNEROSZEVALLOS, L. Characterization of starch from two ecotypes of Andean achira roots (Canna edulis). Journal of Agricultural and Food Chemistry, v. 57, n. 16, p. 73637368, 2009.

DEWI, K. Prospect of Canna (Canna edulis Ker.) rhizome as a feedstock for bioethanol production. Comparative Biochemistry and Physiology Part A: Molecular \& Integrative Physiology, v. 153, n. 2, suppl., p. S215, 2009.

DHITAL, S.; BRENNAN, C.; GIDLEY, M. J. Location and interactions of starches in planta: effects on food and nutritional functionality. Trends in Food Science \& Technology, v. 93, n. 1, p. 158-166, 2019.

FONSECA-FLORIDO, H. A.; GÓMEZ-ALDAPA, C. A.; LÓPEZ-ECHEVARRÍA, G.; VELAZQUEZ, G.; MORALES-SÁNCHEZ, E.; CASTRO-ROSAS, J.; MÉNDEZ-MONTEALVO, G. Effect of granular disorganization and the water content on the rheological properties of amaranth and achira starch blends. LWT Food Science and Technology, v. 87, n. 1, p. 280-286, 2018.

FONSECA-FLORIDO, H. A.; GÓMEZ-ALDAPA, C. A.; VELAZQUEZ, G.; HERNÁNDEZ-HERNÁNDEZ, E.; MATA-PADILLA, J. M.; SOLÍS-ROSALES, S. G.; MÉNDEZ-MONTEALVO, G. Gelling of amaranth and achira starch blends in excess and limited water. $L W T$ Food Science and Technology, v. 81, n. 1, p. 265-273, 2017.

FONSECA-FLORIDO, H. A.; MÉNDEZ-MONTEALVO, G.; VELAZQUEZ, G.; GÓMEZ-ALDAPA, C. A. Thermal study in the interactions of starches blends: amaranth and achira. Food Hydrocolloids, v. 61, n. 1, p. 640-648, 2016.

FUENTES, C.; PEREZ-REA, D.; BERGENSTÅHL, B.; CARBALlO, S.; SJÖÖ, M.; NILSSON, L. Physicochemical and structural properties of starch from five Andean crops grown in Bolivia. International Journal of Biological Macromolecules, v. 125, n. 1, p. 829-838, 2019.

GÓMEZ-ALDAPA, C. A.; CASTRO-ROSAS, J.; RANGEL-VARGAS, E.; NAVARRO-CORTEZ, R. O.; CABRERA-CANALES, Z. E.; DÍAZ-BATALLA, L.; MARTÍNEZ-BUSTOS, F.; GUZMÁN-ORTIZ, F. A.; FALFAN-CORTES, R. N. A modified achira (Canna indica $\mathrm{L}$.) starch as a wall material for the encapsulation of Hibiscus sabdariffa extract using spray drying. Food Research International, v. 119, n. 1, p. 547-553, 2019.

GRUNINA, N. A.; TSERETELI, G. I.; BELOPOLSKAYA, T. V.; SMIRNOVA, O. I. Thermal properties of frozen water in the native and amorphous starches with various hydration degrees. Carbohydrate Polymers, v. 132, n. 1, p. 499-508, 2015.

HUANG, J.; ZHAO, L.; MAN, J.; WANG, J.; ZHOU, W.; HUAI, H.; WEI, C. Comparison of physicochemical properties of B-type nontraditional starches from 
different sources. International Journal of Biological Macromolecules, v. 78, n. 1, p. 165-172, 2015.

HUANG, Y.; JIN, Y.; FANG, Y.; LI, Y.; ZHAO, H. Simultaneous utilization of non-starch polysaccharides and starch and viscosity reduction for bioethanol fermentation from fresh Canna edulis Ker. tubers. Bioresource Technology, v. 128, n. 1, p. 560-564, 2013a.

HUANG, Y. H.; JIN, Y. L.; FANG, Y.; LI, Y. H.; ZHANG, G. H.; XIAO, Y.; CHEN, Q.; ZHAO, H. Simultaneous saccharification and fermentation (SSF) of non-starch polysaccharides and starch from fresh tuber of Canna edulis Ker at a high solid content for ethanol production. Biomass and Bioenergy, v. 52, n. 1, p. 8-14, 2013b.

HUANG, Y. H.; JIN, Y. L.; FANG, Y.; LI, Y. H.; ZHANG, G. H.; XIAO, Y.; CHEN, Q.; ZHAO, H. Simultaneous saccharification and fermentation (SSF) of non-starch polysaccharides and starch from fresh tuber of Canna edulis Ker at a high solid content for ethanol production. Biomass and Bioenergy, v. 52, n. 1, p. 8-14, 2013c.

JIRANUNTAKUL，W.; PUTTANLEK，C.; RUNGSARDTHONG, V.; PUNCHA-ARNON, S.; UTTAPAP, D. Microstructural and physicochemical properties of heat-moisture treated waxy and normal starches. Journal of Food Engineering, v. 104, n. 2, p. 246-258, 2011.

KLAOCHANPONG, N.; PUTTANLEK, C.; RUNGSARDTHONG, V.; PUNCHA-ARNON, S.; UTTAPAP, D. Physicochemical and structural properties of debranched waxy rice, waxy corn and waxy potato starches. Food Hydrocolloids, v. 45, n. 1, p. 218-226, 2015.

LAN, X.; LI, Y.; XIE, S.; WANG, Z. Ultrastructure of underutilized tuber starches and its relation to physicochemical properties. Food Chemistry, v. 188, n. 1, p. 632-640, 2015.

MISHRA, T.; DAS, A. P.; SEN, A. Phytochemical screening and in-vitro antioxidant profiling of solvent fractions of Canna edulis Ker Gawler. Free Radicals and Antioxidants, v. 2, n. 1, p. 13-20, 2012.

PAGÁN-JIMÉNEZ, J. R.; RODRÍGUEZ-RAMOS, R.; REID, B. A.; VAN DEN BEL, M.; HOFMAN, C. L. Early dispersals of maize and other food plants into the southern Caribbean and northeastern South America. Quaternary Science Reviews, v. 123, n. 1, p. 231-246, 2015.

PEREZ, C. Estadistica practica con statgraphics. 2. ed. Zaragosa: Prentice Hall, 2002.

PULIDO DÍAZ, A.; LOURDIN, D.; DELLA VALLE, G.; FERNÁNDEZ QUINTERO, A.; CEBALLOS, H.; TRAN, T.; DUFOUR, D. Thermomechanical characterization of an amylose-free starch extracted from cassava (Manihot esculenta, Crantz). Carbohydrate Polymers, v. 157, n. 1, p. 1777-1784, 2017.
PUNCHA-ARNON, S.; JIRANUNTAKUL, W.; UTTAPAP, D. Effects of crosslinking temperature and time on microstructure and stability of cassava starch microspheres. Carbohydrate Polymers, v. 134, n. 1, p. 344-352, 2015.

PUNCHA-ARNON, S.; PUTTANLEK, C.; RUNGSARDTHONG, V.; PATHIPANAWAT, W.; UTTAPAP, D. Changes in physicochemical properties and morphology of canna starches during rhizomal development. Carbohydrate Polymers, v. 70, n. 2, p. 206-217, 2007.

PUNCHA-ARNON, S.; PATHIPANAWAT, W.; PUTTANLEK, C.; RUNGSARDTHONG, V.; UTTAPAP, D. Effects of relative granule size and gelatinization temperature on paste and gel properties of starch blends. Food Research International, v. 41, n. 5, p. 552-561, 2008.

ŠÁRKA, E.; DVOŘÁČEK, V. New processing and applications of waxy starch: a review. Journal of Food Engineering, v. 206, n. 1, p. 77-87, 2017.

SJÖÖ, M.; NILSSON, L. Starch in food. 2. ed. New York: Woodhead Publishing, 2018.

THITIPRAPHUNKUL，K.; UTTAPAP， D.; PIYACHOMKWAN, K.; TAKEDA, Y. A comparative study of edible canna (Canna edulis) starch from different cultivars: part I. Chemical composition and physicochemical properties. Carbohydrate Polymers, v. 53, n. 3, p. 317-324, 2003a.

THITIPRAPHUNKUL，K.; UTTAPAP， D.; PIYACHOMKWAN, K.; TAKEDA, Y. A comparative study of edible canna (Canna edulis) starch from different cultivars: part II. Molecular structure of amylose and amylopectin. Carbohydrate Polymers, v. 54, n. 4, p. 489-498, 2003 b.

WANDEE, Y.; UTTAPAP, D.; PUNCHA-ARNON, S.; PUTTANLEK, C.; RUNGSARDTHONG, V.; WETPRASIT, N. Quality assessment of noodles made from blends of rice flour and canna starch. Food Chemistry, v. 179, n. 1, p. 85-93, 2015.

WANDEE, Y.; UTTAPAP, D.; PUNCHA-ARNON, S.; PUTTANLEK, C.; RUNGSARDTHONG, V.; WETPRASIT, N. In vitro fermentabilities of raw and cooked canna starches and their derivatives. Journal of Functional Foods, v. 34, n. 1, p. 461-469, 2017.

XIE, F.; ZHANG, W.; GONG, S.; GU, X.; LAN, X.; WU, $\mathrm{J} . ;$ WANG, Z. Investigating lignin from Canna edulis Ker residues induced activation of $\alpha$-amylase: kinetics, interaction, and molecular docking. Food Chemistry, v. 271, p. 62-69, 2019.

ZHANG, J.; CUI, J.; XIAO, L.; WANG, Z. The combination of atomic force microscopy and sugar analysis to evaluate alkali-soluble Canna edulis Ker pectin. Food Chemistry, v. 156, n. 1, p. 64-71, 2014. 
ZHANG, J.; WANG, Z.-W. Thermal analysis and physiological behavior of cellulose/pectin complex from Canna edulis Ker by-product. Carbohydrate Polymers, v. 87, n. 2, p. 1153-1158, 2012.

ZHANG, J.; WANG, Z.-W. Soluble dietary fiber from Canna edulis Ker by-product and its physicochemical properties. Carbohydrate Polymers, v. 92, n. 1, p. 289296, 2013.
ZHANG, J.; WANG, Z.-W.; MI, Q. Phenolic compounds from Canna edulis Ker residue and their antioxidant activity. LWT - Food Science and Technology, v. 44, n. 10, p. 2091-2096, 2011a.

ZHANG, J.; WANG, Z.-W.; YU, W.-J.; WU, J.-H. Pectins from Canna edulis Ker residue and their physicochemical characterization. Carbohydrate Polymers, v. 83, n. 1, p. 210-216, $2011 b$. 